Middle-East Journal of Scientific Research 4 (1): 10-19, 2009

ISSN 1990-9233

(C) IDOSI Publications, 2009

\title{
Mode of Entry as a Predictor of Success in Final Year Bachelor of Education Degree Examinations in Universities in Ekiti and Ondo States, Nigeria
}

\author{
T.O. Adeyemi
}

Department of Educational Foundations and Management, University of Ado-Ekiti, Ado-Ekiti, Nigeria

\begin{abstract}
This paper investigated the mode of entry as a predictor of success in final year bachelor of education degree examinations in universities in Ekiti and Ondo States, Nigeria. The study population comprised all the 1810 final year 400 level students in the two universities offering education courses namely University of Ado-Ekiti in Ekiti State and Adekunle Ajasin University in Ondo State, Nigeria. Out of this population, 760 final year 400 level students who scored cumulative grade point average of 3.50 and above in the final bachelor of education degree in 2007/2008 academic year in the two universities were selected for the study. The instrument used was an inventory while the data collected were analysed using percentages, correlation matrix and multiple regression. The finding revealed that the pre-degree mode of entry is the best predictor of success in the final year bachelor of education degree in the universities. Based on the findings, it was recommended that more emphasis should be given to the pre-degree mode of entry in the admission process into universities in the two States in a bid to achieve the goals of the National Policy on Education in providing the much needed qualitative education in Nigerian universities.
\end{abstract}

Key word: Mode $\cdot$ Entry $\cdot$ Predictor $\cdot$ Success $\cdot$ University $\cdot$ Examinations

\section{INTRODUCTION}

University education in Ekiti and Ondo States, Nigeria dated back to 1980s. The modes of admission of candidates into first degree programmes in the universities are in three major forms. These include admissions through the direct entry, admissions through the universities matriculation examinations (UME) and admissions through the pre - degree programme. Admissions through the universities matriculation examinations (UME) and direct entry are being handled by the Joint Admissions and Matriculation Board while admission through the pre-degree programme is being handled by the universities themselves [1].

The Joint Admissions and Matriculation Board (JAMB) was established by the Federal Government of Nigeria through Act 2 of 1978 to regularize the intake of students into the universities and solve the problem of multiple admissions given to some candidates at the expense of others [2,3]. Like other examining bodies in Nigeria, the Joint Admissions and Matriculation Board has been subjected to series of criticisms. For instance, Olatuga [4] alleged that the question of admitting incompetent candidates would not arise if each university was allowed to conduct its own entrance examination and select its own candidates.

Besides, the initiatives of the Joint Admissions and Matriculation Board have been widely jeopardized by the widely reported cases of examination malpractices [5]. Records indicate that in 1995 alone, the Joint Admissions and Matriculation Board cancelled the result of 81,066 candidates $(21.3 \%)$ who were involved in cheating in the examinations [6]. In 1998, out of 322,020 candidates who sat for the university matriculation examinations, 8,194 candidates had their results cancelled due to their involvement in various forms of examination malpractices [7]. Similar findings were made by other researchers in years 2002 and 2003 [8]. From the above, it appears that the objectives of establishing the Joint Admissions and Matriculation Board are being defeated. This might perhaps have been the reason why many Nigerian universities started the pre-degree programme as alternative to the Joint Admissions and Matriculation Board.

Examinations in Nigerian schools dated back to the advent of formal education. As a former British Colony, the system of examination in Nigeria took after the British system. This importance of examinations in the country'

Corresponding Author: T.O. Adeyemi, Department of Educational Foundations and Management, University of Ado-Ekiti, Ado-Ekiti, Nigeria 
educational system has been entrenched in the National Policy of Education [9]. In the university setting, success in an examination is being assessed through the cumulative grade point average obtained by students in all the courses registered from the 100 level to the final year level. As such, a student is deemed to have performed very well to the level of second class upper division if the cumulative grade point average is between 3.50 and 4.49; or first class if the cumulative grade point average is 4.50 and above. Hence, the cumulative grade point average determines the success level of a student from one semester to another. The grading of the cumulative grade point average is such that 4.50 and above is first class, 3.50 to 4.49 is second class upper division, 2.50 to 3.49 is second class lower division, 1.50 to 2.49 is third class, 1.00 to 1.49 is ordinary pass degree while below 1.00 is failure [10,11].

Literature Review: The term 'academic success' is described as the scholastic standing of a student at a given moment. It refers to how an individual is able to demonstrate his or her intellectual abilities. This scholastic standing could be explained as the grades obtained in a course or groups of courses; and the way in which a student has attained the grades including the time he or she passed examination two after passing examination one [12-14]. Daniels and Schouten [12] therefore argued that a prediction of a future examination result could be made with reasonable success on the basis of the results of an earlier examination and that grades may serve as prediction measures and as criterion measures.

As a measure of prediction, Dockery [15] investigated the effects of intelligence quotient on academic achievement and found that achievement scores increased as the intelligence quotient increased. Eysenck [16] agreed with this finding and remarked intelligence quotient testing has been extremely successful on the practical level predicting academic success from early childhood to university degree. Findings made by Al-Shorayye [17] and Adeyemi [18] led credence to this point. Findings made by Peers and Johnston [19] confirmed the validity of the number and grades of passes in the Scottish Certificate of Education in predicting first year and final year university performance. Findings made by Gay [20] in the USA also confirmed the fact that high school grades are good predictors of college grades. In the same vein, Entwistle and Wilson [21] too, found that students with three ' $A$ ' level passes did better than students with two in the university.
Researchers have made divergent findings on the predictive validity of some examinations [22-27]. While some researchers $[22,23,26]$ found that performance in a lower level examination was significantly related to the performance in a higher level examination, others researchers [25,27] found no significant relationship between the performance in lower level examinations and performance in higher institutions. Considering these divergent findings, this study intended to examine the mode of entry of students into universities in Ekiti and Ondo States, Nigeria in other to correct any erroneous impression. The study would investigate which of the modes of entry into universities in the two states best predict success in the final bachelor of education degree examinations.

Statement of the Problem: The decay in the Nigerian educational system calls for attention. The search for the most desirable mode of selecting candidates for admission into the Nigerian universities continues [28]. This is evidenced by the public opinion about the standard of the students graduating from the universities. More disturbing is the common observation that many graduates from certain universities are being rejected by the labour market because of low academic competence. Some educationists have argued that the incompetence of many university students is precipitated by the selection procedure of Joint admissions and matriculation Board (JAMB) which fails to control the number and quality of candidates being admitted into the universities annually [29]. The problem has been blamed on the Board's system of admission [26]. There have been conflicting findings on the predictive strength of certain modes of entry in predicting performance at final year university examinations $[25,30]$. The problem of this study therefore was to determine which mode of entry into the universities best predicts the success of students in the final bachelor of education degree examinations in universities in Ekiti and Ondo States, Nigeria. In addressing this problem, the following research questions were raised.

- What is the number of students who scored 3.5 and above Cumulative Grade Point Average (CGPA) in the final 400 level examinations for the Bachelor of education degree at the University of Ado-Ekiti, Ekiti State and the Adekunle University, Ondo State, Nigeria on the basis of their mode of entry? 
- Is there any significant relationship between the mode of entry of final year 400 level education students into the universities and high cumulative grade point average of 3.5 and above in the bachelor of education degree examinations in universities in Ekiti and Ondo States, Nigeria?

- Is there any significant difference in the cumulative grade point average for the bachelor of education degree between the University of Ado-Ekiti in Ekiti State and Adekunle Ajasin University in Ondo State, Nigeria on the basis of their mode of entry?

- Which of the direct entry, universities matriculation examinations and pre-degree modes of entry will best predict high cumulative grade point average of 3.5 and above in the bachelor of education degree in the two universities?

\section{MATERIALS AND METHODS}

This study adopted the ex-post facto and correlational research design. An ex-post facto research as an after fact study involving the collection of existing data [20] while a correlational research is a study involving the determination of the degree to which variables are related [31]. In this regard, the study population comprised all the 1810 final year 400 level students in the two universities offering education courses namely University of Ado-Ekiti in Ekiti State and Adekunle Ajasin University in Ondo State, Nigeria. Out of this population, 760 final year 400 level students who scored cumulative grade point average of 3.50 and above in the final bachelor of education degree in 2007/2008 academic year in the two universities were purposively selected for the study. This was made up of 450 students at the University of Ado-Ekiti in Ekiti State and 310 students at the Adekunle Ajasin University in Ondo State for the 2007/2008 academic year.

The instrument used for the study was an inventory titled 'mode of entry into universities inventory' It requested information on students' enrolment in education courses in the various departments of the faculty of education in each university. It also requested for data on the modes of entry of the final year 400 level students into the universities and data on the cumulative grade point average obtained by these students in the final bachelor of education degree examinations. The validity of the instrument was determined by experts in Test and Measurement who matched the items of the inventory with the hypotheses to ascertain whether or not the instrument actually measured the content area of the study. The reliability was determined through the testretest method. The instruments were administered to 40 respondents drawn from two universities outside the study area. After a period of two weeks, the instruments were re-administered to the same respondents. The data collected were analyzed using the Pearson Product Moment reliability. A correlation coefficient of 0.81 was obtained indicating that the instrument was reliable for the study. The data collected were analyzed using Correlation Matrix, Chi Square test, One-way Analysis of Variance and Multiple Regression. The hypotheses were tested for significance at 0.05 alpha level.

\section{RESULTS}

Question 1: What is the number of students who scored 3.5 and above Cumulative Grade Point Average (CGPA) in the final 400 level examinations for the Bachelor of education degree at the University of Ado-Ekiti, Ekiti State and the Adekunle University, Ondo State, Nigeria on the basis of their mode of entry?

In answering this question, data on the number of final year 400 level students in 2007/2008 academic year who were admitted into the University of Ado-Ekiti, Ekiti State and Adekunle Ajasin University, Ondo State, Nigeria through the three different modes of admission namely pre-degree, universities matriculation examinations (UME) and direct entry were collected through an inventory. Data on the number of these students who scored he cumulative grade point average (CGPA) of 3.5 and above in the final 400 level examinations for the Bachelor of education degree in the two universities were also collected. The data were analyzed using percentages. The findings are presented in Table 1.

As indicated in Table 1, the pre-degree mode of entry into the two universities had the largest number of students who obtained 3.5 and above cumulative grade point average (CGPA) among all the final year 400 level education students in the two universities. The predegree mode of entry accounted for $58.2 \%$ of the intakes at the University of Ado-Ekiti and $42.3 \%$ at the Adekunle Ajasin University, Ondo State respectively. This was followed by the university matriculation examination (UME) mode of entry which accounted for $26.7 \%$ of the intakes at the University of Ado-Ekiti, Ekiti State. and $37.7 \%$ of the intakes into the Adekunle Ajasin University, Onto State. The direct entry mode of entry had the least 


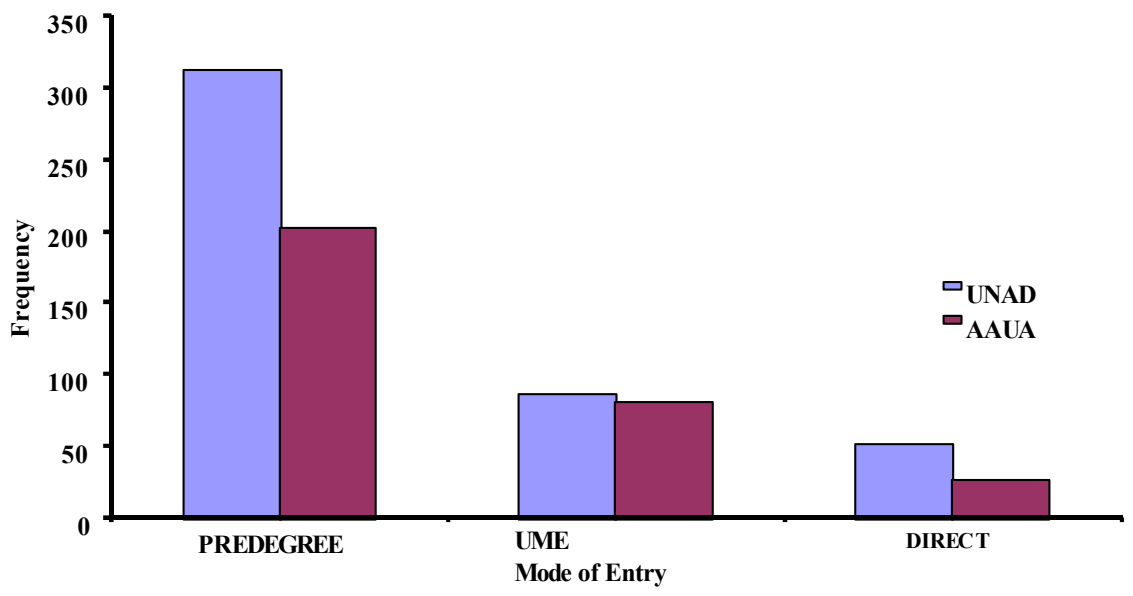

Fig. 1: Mode of Entry and CGPA Obtained by Final Year 400 Level Students in Universities in Ekiti and Ondo States, Nigeria

Table 1: Number of Final year Education Students who Scored 3.5 and above Cumulative Grade Point Average (CGPA) in the two Universities

\begin{tabular}{|c|c|c|c|c|c|c|c|}
\hline Modes of Entry & $\mathrm{N}$ & Pre-degree & $\%$ & UME & $\%$ & Direct Entry & $\%$ \\
\hline University of Ado-Ekiti, Ekiti State & 450 & 262 & 58.2 & 120 & 26.7 & 68 & 15.1 \\
\hline Adekunle Ajasin University, Ondo State & 310 & 131 & 42.3 & 117 & 37.7 & 62 & 20.0 \\
\hline Total & 760 & 393 & 51.7 & 237 & 31.2 & 130 & 17.1 \\
\hline
\end{tabular}

number of students who scored a cumulative grade point average (CGPA) of 3.5 and above among all the final year 400 level education students in the two universities. The direct entry mode of entry accounted for only $15.1 \%$ of the intakes at the University of Ado-Ekiti and 20. $0 \%$ at the Adekunle Ajasin University, Onto State. The graph depicting the relationship between the modes of entry and cumulative grade point average (CGPA) obtained by the students is shown in Figure 1.

Figure 1 shows the relationship between each of the three modes of entry into the two universities in Ekiti and Ondo States, Nigeria and the cumulative grade point average (CGPA) of 3.5 and above obtained by the students in the final 400 level bachelor of education degree examinations. The graph slopes down form the highest CGPA to the lowest CGPA along the line of the mode of entry into the universities. The graph also shows vividly that students in the two universities who had the highest CGPA were those who entered the universities through the pre-degree mode of entry. This implies that more the number of students who entered the universities through the pre-degree mode of entry, the more the number of number of such students who obtained higher cumulative grade point average of 3.5 and above in the final bachelor of education degree examination in the two universities.
Question 2: Is there any significant relationship between the mode of entry of final year 400 level education students into the universities and high cumulative grade point average of 3.5 and above in the bachelor of education degree examinations in universities in Ekiti and Ondo States, Nigeria?

In answering this question, the question was transformed into the following hypothesis.

Ho: There is no significant relationship between the mode of entry of final year 400 level education students into the universities and high cumulative grade point average of 3.5 and above in the bachelor of education degree examinations in universities in Ekiti and Ondo States, Nigeria.

In testing this hypothesis, data on the number of final year 400 level education students in the 2006/2007 academic year in the two universities who were admitted into the two universities through the three different modes of admission namely pre-degree, university matriculation examination (UME) and direct entry modes were collected through the inventory. Data on the cumulative grade point average (CGPA) of the students in the final bachelor of education degree examinations in 2006/2007 academic year were also collected. The hypothesis was tested using the correlation matrix. The results are presented in Table 2. 
Middle-East J. Sci. Res., 4 (1): 10-19, 2009

Table 2: Correlation matrix on mode of entry and cumulative grade point average (CGPA) at the University of Ado-Ekiti, Ekiti State, Nigeria

\begin{tabular}{llll}
\hline Variables & Final CGPA & Direct Entry & UME \\
\hline Final CGPA & 1.00 & & \\
Direct Entry & 0.18 & 1.00 & \\
Pre-degree & 0.41 & 0.29 & 1.00 \\
UME & 0.32 & 0.27 & 0.26 \\
\hline
\end{tabular}

$\mathrm{p}<0.05$

Table 3: Correlation matrix on mode of entry and cumulative grade point average (CGPA) at Adekunle Ajasin University in Ondo State Nigeria

\begin{tabular}{llll}
\hline Variables & Final CGPA & Direct Entry & UME \\
\hline Final CGPA & 1.00 & & Pre-degree \\
Direct Entry & 0.16 & 1.00 & 1.00 \\
Pre-degree & 0.36 & 0.28 & 0.24 \\
UME & 0.27 & 0.26 & 1.00 \\
\hline $\mathrm{p}<0.05$ & & &
\end{tabular}

As indicated in Table 2, the correlation matrix shows the correlation coefficients ' $r$ ' between each pair of variables. Since the larger the value of ' $r$ ', the stronger the association between the two variables [32], therefore, the pairs of variables with large correlation coefficients had strong association with each other. In this regard, the pre-degree mode of entry had the largest correlation coefficient ' $r$ ' of 0.41 among the three modes of admission into the universities indicating that it had the strongest relationship with cumulative grade point average of 3.5 and above in the final 400 level bachelor of education degree examinations in the university. This was followed by the universities matriculation examination (UME) mode of entry which had a correlation coefficient of 0.32 with cumulative grade point average of 3.5 and above in the final 400 level bachelor of education degree examinations The direct level mode of entry had the lowest correlation coefficient of 0.18 with cumulative grade point average of 3.5 and above in the final 400 level bachelor of education degree examinations The findings in respect of the correlation matrix for the Adekunle Ajasin University in Ondo State Nigeria are indicated in Table 3.

In Table 3, the findings show that the pre-degree mode of entry also had the largest correlation coefficient ' $r$ ' of 0.36 among the three modes of admission into the universities. This shows that pre $=$ degree mode of entry had the strongest relationship with cumulative grade point average of 3.5 and above in the final 400 level bachelor of education degree examinations in the universities. This was followed by the universities matriculation examination (UME) mode of entry which had a correlation coefficient of 0.27 with cumulative grade pointes, Nigeria average of 3.5 and above in the final 400 level bachelor of education degree examinations The direct level mode of entry also had the lowest correlation coefficient of 0.16 with cumulative grade point average of 3.5 and above in the final 400 level bachelor of education degree examinations.

Question 3: Is there any significant difference in the cumulative grade point average for the bachelor of education degree between the University of Ado-Ekiti in Ekiti State and Adekunle Ajasin University in Ondo State, Nigeria on the basis of their mode of entry?

In addressing this problem, the question was transformed into the following hypothesis.

Ho: There is no significant difference in the cumulative grade point average for the bachelor of education degree between the University of Ado-Ekiti in Ekiti State and Adekunle Ajasin University in Ondo State, Nigeria on the basis of their mode of entry.

Testing this hypothesis, data on the number of final year 400 level students who were admitted into the universities through the three different modes of admission were collected through the inventory. Data on the cumulative grade point average (CGPA) of the students in the final bachelor of education degree examinations in 2006/2007 academic year were also collected. The data were using the Analysis of variance (ANOVA). The results are presented in Table 4.

As indicated in Table 4, the calculated Chi Square (6.452) was greater than the table Chi Square (5.991) at 0.05 alpha level. Hence, the non-hypothesis was rejected indicating that there was a significant difference in the number of students who obtained cumulative grade point average of 3.3 and above in the final 400 level examinations for the bachelor of education degree 
Middle-East J. Sci. Res., 4 (1): 10-19, 2009

Table 4: Chi-Square Output of Modes of Entry into the universities and Cumulative Grade Point Average (CGPA) of 3.5 and Above in the two Universities Modes of Entry

\begin{tabular}{lllllll} 
Universities & Pre-degree & UME & Direct Entry & Total & df & Calculated Chi-Square (Pearson) \\
\hline University of Ado- Ekiti, Ekiti State & 262 & 120 & 68 & 450 & 2 & 6.452 \\
Adekunle Ajasin University, Ondo State & 131 & 117 & 62 & 310 & & \\
\hline Total & 393 & 237 & 130 & 760 & & $\mathrm{p}<0.091$ \\
\hline
\end{tabular}

Table 5: Multiple Regression Analysis on Variables in Respect of University of Ado-Ekiti, Ekiti State, Nigeria

\begin{tabular}{lllll}
\hline Predictor Variables & B & SE B & Beta & T \\
\hline Pre-degree & 0.5321 & 6.4181 & 0.42682 & 0.0000 \\
UME & 0.4134 & 0.001 & 0.3753 & 0.0468 \\
Direct Entry & 0.2417 & 0.0012 & 0.2954 & -2.725 \\
(Constant) & 3.472 & 0.0216 & & 0.0100 \\
\hline
\end{tabular}

Thus, the regression equation derivable from the table 4.1 is:

$\mathrm{Y}=3.472+.5321$ (Pre-degree) +.4134 (UME) +.2417 (Direct Entry)

Multiple R 0.78642

R Square 0.62791

Adjusted R Square $\quad 0.61573$

Standard Error $\quad 0.07425$

Analysis of Variance

\begin{tabular}{llccc}
\hline & df & Sum of Squares & Mean Squares & S \\
\hline Regression & 2 & 6.5742 & 1.4376 & 3.46 \\
Residual & 257 & 4.1591 & 0.00512 & $=000$ \\
\hline
\end{tabular}

Table 6: Multiple Regression Analysis on Variables in Respect of Adekunle Ajasin University Ondo State, Nigeria

\begin{tabular}{llllll}
\hline Predictor Variables & B & SE B & Beta & T \\
\hline Pre-degree & 0.4716 & 5.3724 & 0.41043 & 1.5834 & .0000 \\
UME & 0.4021 & 0.001 & 0.3257 & .0010 \\
Direct Entry & 0.2135 & 0.0011 & 0.2639 & -2.416 \\
(Constant) & 3.134 &. .0212 & .0120 & .0010 \\
\hline
\end{tabular}

Thus, the regression equation derivable from the table 4.2 is:

$\mathrm{Y}=3.134+.4716$ (Pre-degree) +.4021 (UME) +.2135 (Direct Entry)

Multiple R 0.72741

R Square $\quad 0.61752$

Adjusted R Square $\quad 0.60675$

Standard Error $\quad 0.06718$

Analysis of Variance

\begin{tabular}{lllll}
\hline & df & Sum of Squares & Mean Squares & Signif. F \\
\hline Regression & 2 & 6.3281 & 1.4163 & 3.12 \\
Residual & 257 & 4.0745 & 0.00286 & \\
\hline
\end{tabular}

between the University of Ado-Ekiti in Ekiti State and Adekunle Ajasin University in Ondo State, Nigeria on the basis of their modes of entry. The University of Ado-Ekiti in Ekiti State had more final year 400 level students who obtained higher cumulative grade point average (CGPA) of 3.5 and above than in the final 400 level bachelor of education degree examinations than the Adekunle Ajasin University in Ondo State. 
Question 4: Which of the direct entry, universities matriculation examinations and pre-degree modes of entry will best predict high cumulative grade point average of 3.5 and above in the bachelor of education degree in the two universities?

In addressing this problem, the question was transformed into the following hypothesis.

Ho: None of the direct entry, universities matriculation examinations and pre-degree modes of entry will best predict high cumulative grade point average of 3.5 and above in the bachelor of education degree in universities in Ekiti and Ondo States, Nigeria.

In testing this hypothesis, data on the number of final year 400 level education students admitted through the three different modes of pre-degree, universities matriculation examinations and direct entry into the University of Ado- Ekiti, Ekiti State and Adekunle Ajasin University in Ondo State, Nigeria for the bachelor of education degree were collected through the inventory. Data on the cumulative grade point average of the students for the bachelor of education degree in the two universities were also collected. The hypothesis was tested using multiple regression analysis. In this regard, all the predictor variables of modes entry namely predegree, universities matriculation examinations (UME) and direct entry as well as the criterion variable, cumulative grade point average were put into the regression model. The multiple regression output for the predictor variables and the criterion variable in respect of the University of Ado-Ekiti, Ekiti State, Nigeria are presented in Table 5.

As indicated in Table 5, the probability was less than 0.05 for all the variables indicating that there was a significant relationship between all the predictor variables of pre-degree, universities matriculation examinations (UME) and direct entry modes of entry into the universities and the criterion variable, cumulative grade point average (CGPA). All the variables entered the regression equation. The best predictor of success in the final bachelor of education degree was the pre-degree mode of entry which contributed $53 \%$ to the regression equation. This was followed by the universities matriculation examinations (UME) mode of entry which contributed $41 \%$ and the direct entry mode of entry which contributed $24 \%$ to the equation. The multiple regression output for the predictor variables and the criterion variable in respect of the Adekunle Ajasin University in Ondo State, Nigeria are indicated in Table 6.
In Table 6, the probability was also less than 0.05 for all the variables. This shows that there was a significant relationship between all the predictor variables of pre-degree, universities matriculation examinations (UME) and direct entry modes of entry into the universities and the criterion variable, cumulative grade point average (CGPA). All the variables entered the regression equation. The best predictor of success in the final bachelor of education degree was the predegree mode of entry which contributed $47 \%$ to the regression equation. This was followed by the universities matriculation examinations (UME) mode of entry which contributed $40 \%$ and the direct entry mode of entry which contributed $21 \%$ to the equation.

\section{DISCUSSION}

In the foregoing analysis, the predictive strength of the mode of entry of students in predicting success in the final bachelor of education degree in universities in Ekiti and Ondo State, Nigeria was examined. The findings show that there was a significant relationship between students' modes of entry into the universities and obtaining cumulative grade point average of 3.5 and above in the final 400 level bachelor of education degree in universities in Ekiti and Ondo States, Nigeria. The correlation matrix on the relationship between the mode of entry and cumulative grade point average of students in the two universities shows positive relationship between each pair of the variables. This finding was consistent with the findings made by other researchers $[14,17,23,30]$.

The fact that the pre-degree mode of entry had the strongest predictive value out of the three modes of entry was also consistent with the findings of other researchers [22]. The fact that the direct entry mode of entry did not predict success in the examination as the pre-degree mode of entry is an indication that students coming into the universities through the pre-degree performed better in the universities than students entering the universities through the direct entry. This perhaps might be due to the fact that students entering the universities through the pre-degree spent more years of academic work in the universities, that is, 1 year for pre-degree and 4 years for the degree than students who entered through the direct entry and spent 3 years. This finding was in consonance with the findings in previous studies $[19,33,34]$. The findings however were contrary to the findings of other researchers $[35,36]$. The fact the universities matriculation examination (UME) mode of entry was the second 
strongest predictor of success in the examinations implies that even through UME students spent four years in the universities, their exposure to university academic work might perhaps have made the universities matriculation examination (UME) mode of entry a better predictor of success in the final bachelor of education degree than the direct entry mode of entry. This finding agreed with those of previous researchers [28,29].

The finding of no significant difference in the cumulative grade point average obtained by final year 400 level students in the bachelor of education degree in the university in Ekiti State and the university in Ondo State, Nigeria implies that there was almost the same trend in the pattern of relationship of the each of the three modes with the cumulative grade point average of 3.5 and above in the final 400 level bachelor of education degree examinations in the universities. This finding agreed with the findings of previous researchers [26,37,38].

The strongest contribution made by pre-degree mode of entry to the regression equation shows that the pre-degree mode of entry is the best predictor of success in the final bachelor of education degree in each of the two universities. The finding was however consistent with those of other researchers $[39,25]$. The findings were however at variance with those made by other researchers $[40,41]$ and it suggests further research in this area of study.

\section{CONCLUSION}

Considering the findings, it was concluded that the pre-degree is the best predictor of success in the final year bachelor of education degree in universities in Ekiti and Ondo States, Nigeria. This is evident in the findings that students who entered the universities through the pre-degree mode of entry were in the largest number among students who scored the cumulative grade point average (CGPA) in the final year bachelor of education degree examinations in the two universities. The findings have also led the researcher to conclude that the direct entry mode of entry is worst predictor of success in the final year bachelor of education degree examinations in the universities.

Recommendations: Based on the findings of the study, it is recommended that more emphasis should be given to admission into the universities through the pre-degree mode of entry as the findings of this study has isolated this variable as the best predictor of success in the final bachelor of education degree examinations in the universities. As such, the universities should deemphasize the admission of students through the direct entry and increase admission through the pre-degree programme in a bid to achieve the much needed qualitative education in the universities as entrenched in the National Policy on Education [9].

\section{REFERENCES}

1. Akper, P.T. and M.D. Fagbongbe, 1999. University autonomy under the military; Paper presented at the Law Teachers' Conference held at the University of Ado- Ekiti pp: 2-10.

2. JAMB 1998. JAMB Brochure, Abuja: Joint Admissions and Matriculation Examinations, 2.

3. Akintoye, S., F. Egbemode, C. Ogbuka and R. Odusanya, 2000. Jamb: Cross of an Empire; The Punch, June, pp: 24.

4. Olatuga, A., 1997. Campaign against examination malpractices and students' cults: an overview from COPSSON, paper presented at the National Summit on Legal, policy and organizational framework held at the International Conference Centrs: Abuja, Nigeria from $2^{\text {nd }}$ to $4^{\text {th }}$ December; 1-5.

5. Olugbile, S., 2004. Exam malpractice rocks Zamfara, Lagos: Punch Education, The Punch 17 (19166) Friday, September, 10: 40-41.

6. Daisi, K., 1997. Legal, policy and organizational framework for the campaign against examination malpractices and students' cults" paper presented at the National Summit on Legal, policy and organizational framework held at the International Conference Centrs: Abuja, Nigeria from $2^{\text {nd }}$ to $4^{\text {th }}$ December; pp: 4-12.

7. Salim, R.A., 1998. Scientific fraud: JAMB arbitrators, The Punch; Tuesday, $28^{\text {th }}$ July, pp: 12-14.

8. Igwe, R., 2004. Examination malpractice rocks Zamfara, Lagos: Punch Education. The Punch, 17 $(19,166)$ September 10: 41.

9. FGN 2004. National policy on education, NERDC Yaba, Lagos, 7: 44-45.

10. University of Ado-Ekiti, 1999. UNAD Handbook, 2004/2005 Ado-Ekiti: University of Ado-Ekiti; Nigeria; pp: 21-36.

11. Adekunle Ajasin University, 2000. Handbook 2004/2005 Akungba: Adekunle Ajasin University Akungba-Akoko, Nigeria, pp: 12-18. 
12. Daniels, M. and J. Schouten, 1970. Education in Europe: the screening of students, problems of assessment and prediction of academic performance, Council for Cultural Co-operation of the Council of Europe. London: George Harrap Co. Ltd, 65.

13. Addison, J.F., 1990. Examinations and the Upper Secondary Curricula in Selected Anglo-Phone and Franco-Phone West African Countries" Unpublished $\mathrm{PhD}$ Thesis, Institute of Education, University of London UK. June, pp: 13-16.

14. Owoyemi, N., 2000. Moderation and standardisation of continuous and terminal assessment scores in junior secondary certificate examination and primary school leaving certificate assessment Paper delivered at the senior staff seminar, Ministry of Education, Ado $2^{\text {nd }}$ March, 2.

15. Dockery, K.A., 1986. The Effects of IQ, Sex and School Entrance Age on the Achievement and Self Esteem of Ten-to -Eleven Year old Students" Unpublished PhD Thesis, Temple University USA. Dissertation Abstracts on CD Rom. Order No AAC 8611836.

16. Eysenck, H., 1995. Clever Measures, The Times Higher Education Supplement 1160. January 27: 15.

17. Al-Shorayye, S.R., 1995. The effect of admissions policy, socio-economic factors and demographic and personal considerations on students' performance at Kuwait University. Unpublished $\mathrm{PhD}$ Thesis, University of Hull UK, pp: 142-145.

18. Adeyemi, T.O., 1998. School and teachers variables associated with the performance of students in the senior secondary certificate examinations in Ondo-State, Nigeria. Unpublished $\mathrm{PhD}$ Thesis, University of Hull, UK, 203-208.

19. Peers, I.S. and M. Johnston, 1994 Influence of learning context on the relationship between A- Level attainment and final degree performance: A metaanalytic review, British Journal of Educational Psychology, 64: 1-15.

20. Gay, L.R., 1996. Educational research: competencies for analysis and application; Upper Saddle River, New Jersey: Merrill, Prentice-Hall Inc, pp: 249-305.

21. Entwistle, N.J. and J.D. Wilson, 1977. Degrees of Excellence: The Academic Achievement Game London: Hodder and Stoughton, 3: 10-12, 19.

22. Ubokobong, H.E., 1993. Predicting educational performance at tertiary level on the basis of secondary level performance, International Journal of Mathematical Education in Science and Technology, 24(2): 287.
23. Itsuokor, D.E., 1994. Performance of Nigerian Students in Two Group Intelligence Tests with Different Cultural Backgrounds, Studies in Educational Evaluation, 20: 199.

24. Alonge, M.F., 1998. Implications of probabilistic models of item analysis to educational evaluation, Journal of Educational Research, 2: 50-56.

25. Omonijo, A.R., 2001. Junior secondary certificate results in integrated science as a predictor of performance in science and mathematics in the senior secondary certificate examinations. Unpublished M.Ed Thesis, University of Ado-Ekiti, Nigeria 79- 82.

26. Adeyemo, G.A., 2001. Teacher and student variables as correlates of achievement in Integrated Science in Ibadan North Local Government Area of Oyo State Unpublished M.Ed Thesis, Faculty of Education, University of Ado-Ekiti; Nigeria, pp: 40-45.

27. Adelugba, O.O., 2003. Students' performance in junior secondary school certificate examinations as predictor of performance in senior school certificate examinations in Ekiti State, Nigeria." Unpublished M.Ed Thesis, University of Ado-Ekiti; Nigeria, pp: 68-70.

28. Asaolu, A.G., 2003. Predictive validity of JSC mathematics examination on the performance of students in science subjects in Ekiti State secondary schools, Unpublished M.Ed Thesis, Faculty of Education, University of Ado-Ekiti; Nigeria, pp: 50-76.

29. Oluwatayo, J.A., 2003. Mode of entry and performance of Nigerian university undergraduates in science courses in selected Nigerian universities. Unpublished $\mathrm{PhD}$ Thesis, University of Ado-Ekiti, Nigeria, 63: 147-165.

30. Aghenta, J.A., 1981. The Economics of Teacher Education: The Case of the B.Ed Degree in Nigeria" Journal of Educational Research Association (JNERA), 2(1): 27-34.

31. Anderson, G., 1998. with Nancy Arsenaut Fundamentals of educational research, London: Falmer Press Taylor \& Francis Inc, 12-13: 110-152.

32. Berenson, M.L. and D.M. Levine, 1979. Basic business statistics: Concepts and applications London: Prentice/Hall International Inc, 325-387: 401-464, 492-515.

33. Ojerinde, A., 1974. Prediction of academic success in school certificate examination from the National Common Entrance examination scores, Unpublished M.Ed Dissertation, Faculty of Education, University of Ife, Ile-Ife, Nigeria. 
34. Alonge, M.F., 1983. The predictive validity of mock Mathematics examinations in West African School Certificate examinations in Ondo State, Nigeria, Unpublished M.Ed thesis, Faculty of Education, University of Ife, Ile-Ife.

35. Othuon, L. and N. Kishor, 1994. Hierarchical linear modelling of predictive validity: The case of Kenya certificate of primary education examination, Studies in Educational Evaluation, 20: 6.

36. Afolabi, B.T., 2002. Comparative analysis of continuous assessment in Mathematics among secondary schools in Ekiti State, Nigeria; Unpublished M.Ed Thesis, Faculty of Education, University of Ado-Ekiti; Nigeria, pp: 72-82.

37. Bandele, S.O., 1985. Predicting success in Mathematics in the JSS of the 6-3-3-4 system in Ijero Local Government Area of Ondo- State, Nigeria Unpublished M.Ed Thesis, Faculty of Education, University of Ibadan, Nigeria.
38. Daramola, C.A., 1998. Differential pattern of study behaviour among male and female gifted students in Nigeria, Journal of Educational Research and Evaluation, 2: 123-127.

39. Durotoluwa, J.O., 2000. Predictive validity of JSS certificate examinations in mathematics: A case study of Owo Local Government Area”. Educational Thought, Journal of Faculty of Education, Ondo State University, Akungba-Akoko, 1(1): 30-34.

40. O'Rourke, B., M.O. Martin and J.F. Hurley, 1989. The scholastic aptitude Test as a Predictor of third-level academic performance, The Irish Journal of Education XXIII,(1): 22-35.

41. Afolabi, E.R. and B.A. Adewolu, 1998. The predictive validity of Osun State junior secondary school examination, Nigerian Journal of Social and Educational Research, 1(1): 35-42. 